\title{
IMPLEMENTASI MODEL PEMBELAJARAN KOOPERATIF TIPE NUMBERED HEAD TOGETHER (NHT) UNTUK MENINGKATKAN AKTIVITAS DAN HASIL BELAJAR TEKNIK DASAR LOMPAT JAUH GAYA JONGKOK PADA SISWA
}

\author{
Ida Bagus Widana Siswaya \\ SMK Negeri 2 Singaraja \\ Email: siswaya.widana@gmail.com
}

\begin{abstract}
ABSTRAK
Penelitian ini bertujuan meningkatkan aktivitas dan hasil belajar lompat jauh gaya jongkok melalui implementasi model pembelajaran kooperatif tipe NHT pada Peserta didik kelas XI Boga 2 SMK Negeri 2 Sigaraja tahun pelajaran 2017/2018.Penelitian ini adalah penelitian tindakan kelas (guru sebagai peneliti) dilaksanakan dalam dua siklus, terdiri dari rencana tindakan, pelaksanaan tindakan, observasi atau evaluasi dan refleksi. Subjek penelitian adalah peserta didik kelas XI Boga 2 SMK Negeri 2 Sigaraja tahun pelajaran 2017/2018., berjumlah 39 orang dengan 21 orang putra dan 18 orang putri. Data dianalisis menggunakan analisis statistik deskriptif.Berdasarkan hasil analisis data didapatkan rata-rata aktivitas belajar lompat jauh gaya jongkok secara klasikal pada observasi awal 6,2(cukup aktif), pada siklus I meningkat menjadi 6,9 (cukup aktif), dan 7,1 (aktif) pada siklus II. Sedangkan presentase ketuntasan hasil belajar kompetensi pengetahuan dari observasi awal sebesar 10,3\% (tuntas), pada siklus I menjadi 74,3\%(tuntas) dan $92,3 \%$ (tuntas) pada siklus II. Peningkatan hasil belajar secara signifikan juga terjadi pada kompetensi sikap dan kompetensi keterampilan. Berdasarkan hasil analisis data dan pembahasan disimpulkan bahwa aktivitas dan hasil belajar lompat jauh gaya jongkok meningkat melalui implementasi model pembelajaran kooperatif tipe NHT pada peserta didik kelas XI Boga 2 SMK Negeri 2 Singaraja tahun pelajaran 2017/2018. Disarankan kepada guru PJOK agar menggunakan model pembelajaran kooperatif tipe NHT karena dapat meningkatkan aktivitas dan hasil belajar lompat jauh peserta didik.
\end{abstract}

Kata Kunci: Model pembelajaran, kooperatif, NHT, aktivitas, hasil belajar, lompat jauh.

\begin{abstract}
This study aims to improve the activity and learning outcomes of squat style long jumps through the implementation of the NHT type of cooperative learning model in class XI Boga 2 SMK Negeri 2 Sigaraja in the school year 2017 / 2018. This study is a classroom action research (teacher as researcher) carried out in two cycle, consisting of a plan of action, implementation of action, observation or evaluation and reflection. The research subjects were students of class XI Boga 2 SMK Negeri 2 Sigaraja in the academic year 2017/2018. There were 39 people with 21 sons and 18 daughters. Data were analyzed using descriptive statistical analysis. Based on the results of data analysis, the average learning activity of squat style long jump learning was classical at the initial observation of 6.2 (quite active), in cycle I it increased to 6.9 (quite active), and 7, 1 (active) in cycle II. While the percentage of completeness of competency learning outcomes of knowledge from the initial observations amounted to $10.3 \%$ (complete), in the first cycle to $74.3 \%$ (complete) and $92.3 \%$ (complete) in the second cycle. Significant improvement in learning outcomes also occurs in competency attitudes and skills competencies. Based on the results of data analysis and discussion it was concluded that the activity and learning outcomes of long jump squat style increased through
\end{abstract}


the implementation of the NHT type cooperative learning model in class XI Boga 2 SMK Negeri 2 Singaraja 2017/2018 school year. It is recommended to the PJOK teacher to use the NHT type of cooperative learning model because it can improve the learning activities and learning outcomes of long jump students.

Keywords: Learning model, cooperative, NHT, activity, learning outcomes, long jump.

\section{PENDAHULUAN}

Proses pembelajaran, guru bukanlah hanya berperan sebagai model atau teladan bagi peserta didik yang diajarnya, tetapi juga sebagai pengelola pembelajaran. Dengan demikian efektivitas proses pembelajaran terletak di pundak guru. Keberhasilan suatu proses pembelajaran sangat di tentukan oleh kualitas atau kemampuan guru, selain itu juga dari segi model-model pembelajaran yang harus direncanakan sesuai dengan situasi dan kondisi peserta didik saat ini. Oleh karenanya, guru harus memahami karakteristik materi, peserta didik, dan metodologi pembelajaran dalam proses pembelajaran terutama berkaitan dengan pemilihan model-model pembelajaran. Dengan demikian, proses pembelajaran akan lebih variatif, inovatif, dan konstruktif sehingga dapat meningkatkan aktivitas dan kreativitas peserta didik (Trianto, 2009: 8-9).

Berdasarkan hasil observasi awal yang dilakukan peneliti pada hari Selasa, 29 Januari 2018 di kelas XI BOGA 2 SMK Negeri 2 Singaraja tahun pelajaran 2017/2018, aktivitas belajar 39 peserta didik (18 peserta didik perempuan dan 21 peserta didik laki-laki) pada materi teknik lompat jauh gaya jongkok yang diperoleh pada saat observasi tergolong cukup aktif. Dapat dilihat dari komponen aktivitas belajar peserta didik yang terdiri dari kegiatan visual, lisan, mendengarkan, metrik, mental dan emosional.

Jadi jika dilihat dari rata-rata aktivitas dan hasil belajar lompat jauh gaya jongkok di atas dapat disimpulkan bahwa, aktivitas dan hasil belajar lompat jauh gaya jongkok kelas XI Boga 2 SMK Negeri 2 Singaraja tidak tuntas. Hal ini disebabkan implementasi model pembelajaran yang belum efektif terhadap materi yang disajikan. Model pembelajaran yang diimplementasikan belum melibatkan atau merangsang peserta didik untuk lebih aktif dan kreatif selama proses pembelajaran berlangsung. Berdasarkan permasalahan di atas, peneliti mencoba memberikan salah satu alternatif pemecahan masalah yaitu dengan menerapkan model pembelajaran kooperatif tipe NHT (Numbered Head Together)dalam pembelajaran PJOK pada materi lompat jauh gaya jongkok. Ketertarikan peneliti menerapkan model pembelajaran kooperatif tipe NHT ini karena (1) model pembelajaran kooperatif dengan tipe NHT adalah model pembelajaran yang sederhana, sehingga model pembelajaran kooperatif ini cocok diterapkan pada peserta didik kelas XI Boga 2 SMK Negeri 2 Singaraja yang belum pernah melakukan pembelajaran kooperatif tipe NHT, (2) pada model pembelajaran ini peserta didik lebih banyak mempunyai kesempatan diskusi kelompok, masing-masing peserta didik memberikan partisipasinya secara maksimal dan setiap peserta didik mempunyai tanggung jawab perseorangan untuk menguasai materi dengan sebaik-baiknya, (3) model pembelajaran kooperatif dengan tipe NHT mengajak peserta didik untuk belajar aktif dan berani dalam mengeluarkan pendapat dalam diskusi kelompok. Apabila ada suatu konsep yang belum dimengerti dan dipahaminya, peserta didik dapat saling isi mengisi dengan peserta didik lain, saling bertukar pikiran sehingga diharapkan konsep yang dimiliki peserta didik benar-benar dapat dipahami dengan baik. Suasana belajar akan lebih kondusif, yang akhirnya berpengaruh terhadap aktivitas dan hasil belajar.

NHT atau penomoran berpikir bersama adalah merupakan jenis pembelajaran kooperatif yang dirancang untuk mempengaruhi pola interaksi peserta didik dan sebagai alternatif terhadap struktur kelas tradisional (Trianto, 2007:62).NHT pertama 
kali dikembangkan oleh Spenser Kagan (1993) untuk melibatkan lebih banyak peserta didik dalam menelaah materi yang tercakup dalam suatu pelajaran dan mengecek pemahaman mereka terhadap isi pelajaran tersebut.

Pemilihan tentang model pembelajaran NHT ini juga dikuatkan oleh hasil penelitian dari peneliti-peneliti sebelumnya diantaranya (1) Penelitian yang dilakukan oleh Sanjaya, I.P.E.Y (2013 :123) dalam skripsinya yang menyimpulkan motivasi dan hasil belajar teknik Lompat jauh gaya jongkok meningkat melalui penerapan model pembelajaran kooperatif tipe NHT pada peserta didik kelas X.5 SMA Negeri 1 Negara tahun pelajaran 2012/2013, (2) Penelitian yang dilakukan oleh Bawa, I.M.L (2012:116) dalam skripsinya yang menyimpulkan aktivitas dan hasil belajar teknik dasar passing sepak bola meningkat melalui penerapan model pembelajaran kooperatif tipe NHT pada peserta didik kelas X.A1 SMK Negeri 2 Singaraja tahun pelajaran 2011/2012, (3) Penelitian yang dilakukan oleh Tirtawati, N.W (2013 :103) dalam skripsinya yang menyimpulkan motivasi dan hasil belajar lompat jauh gaya jongkok meningkat melalui penerapan model pembelajaran kooperatif tipe NHT pada peserta didik kelas XI IPA 3 SMA Negeri 2 Bangli tahun pelajaran 2012/2013.

Berdasarkan uraian di atas, maka peneliti bermaksud mengadakan penelitian dengan judul "Implementasi model pembelajaran kooperatif tipe Numbered Head Together (NHT) untuk meningkatkan aktivitas dan hasil belajar lompat jauh gaya jongkok pada peserta didik kelas XI Boga 2 SMK Negeri 2 Singaraja tahun pelajaran 2017/2018".

Berdasarkan latar belakang yang telah dipaparkan, maka tujuan dari penelitian ini sebagai berikut. (1) Meningkatkan aktivitas belajar lompat jauh gaya jongkok melalui implementasi model pembelajaran koopertif tipe NHT pada peserta didik kelas XI BOGA 2 SMK Negeri 2 Singaraja tahun pelajaran 2017/2018. (2) Meningkatkan hasil belajar lompat jauh gaya jongkok melalui implementasi model pembelajaran koopertif tipe NHT pada peserta didik kelas XI BOGA 2 SMK Negeri 2 Singaraja tahun pelajaran 2017/2018.

\section{METODE PENELITIAN}

Jenis penelitian yang digunakan dalam penelitian ini adalah penelitian tindakan kelas (PTK) atau disebut classroom action research.Penelitian tindakan kelas adalah suatu bentuk penelitian yang bersifat reflektif dengan tindakan-tindakan tertentu agar dapat memperbaiki atau meningkatkan praktikpraktik pembelajaran. Bentuk penelitian tindakan kelas yang akan digunakan dalam penelitian ini adalah guru sebagai peneliti, yaitu guru dalam hal ini penelitian berperan sangat penting dalam proses PTK. Dalam bentuk ini tujuan utama PTK adalah untuk meningkatkan praktek-praktek pembelajaran di kelas dimana guru terlibat secara penuh dalam proses perencanaan, aksi (tindakan), dan refleksi.

Dalam penelitian ini akan dilaksanakan sebanyak dua siklus, dimana masing-masing siklus terdiri dari 2 (dua) kali pertemuan, dalam 1 (satu) kali pertemuan dialokasikan waktu sebanyak $3 \times 45$ menit sesuai dengan kurikulum yang ada disekolah tentang pembelajaran lompat jauh gaya jongkok. Karena keterbatasan waktu, biaya, dan pengetahuan, maka penelitian ini dibatasi sebanyak 2 siklus, sehingga berhasil atau tidak (tuntas atau tidak) tindakan yang diberikan, penelitian ini akan dihentikan, dan direkomendasikan kepada guru PJOK disekolah yang bersangkutan untuk melanjutkannya, tetapi dalam hal ini diharapakan PTK dapat tuntas.

Setiap siklus terdiri dari empat tahapan

yaitu: (1) Perencanaan tindakan, (2) Pelaksanaan tindakan, (3) Observasi/evaluasi, dan (4) Refleksi. Adapun rancangan penelitian tindakan ini dapat dilihat pada Gambar. 


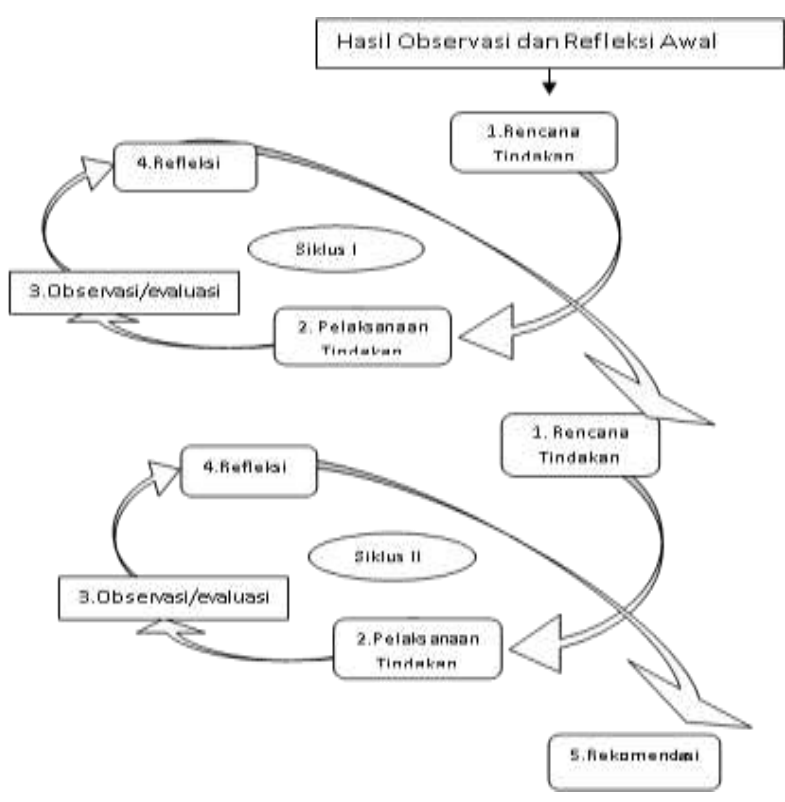

Gambar 1. Siklus PTK

\section{Siklus 1}

\section{Perencanaan Tindakan Siklus I}

a) Menyusun Rencana Pelaksanaan Pembelajaran (RPP) sesuai dengan permasalahan observasi awal yaitu teknik lompat jauh gaya jongkok. (RPP terlampir), b) Menyusun kelompok-kelompok kecil masingmasing 6 atau 7 orang setiap kelompok yang heterogen dari segi keterampilan sehingga terjadi interaksi yang baik antar peserta didik yang tingkat kemampuannya kurang, c) Menyiapkan strategi pembelajaran dengan model pembelajaran kooperatif tipe NHT, d) Menyiapkan sarana dan prasarana yang diperlukan dalam proses pembelajaran lompat jauh gaya jongkok, e) Menyiapakan instrumen observasi/ evaluasi untuk mengetahui aktivitas dan hasil belajar.

Berdasarkan hasil observasi awal, maka peneliti menyusun alternatif pemecahan masalah yang telah teridentifikasi sebagai berikut:

\section{Pelaksanaan siklus I}

Pelaksanaan tindakan pembelajaran pada siklus I terdiri dari 2 kali pertemuan, pertemuan pertama pembelajaran ditekankan pada permasalahan yang ditentukan pada saat observasi awal. Pada siklus I model yang digunakan dalam memecahkan masalah dari hasil observasi adalah model pembelajaran kooperatif tipe NHT.

\section{Observasi/ Evaluasi}

Observasi aktivitas belajar lompat jauh gaya jongkok.

Untuk mengetahui tingkat penguasaan materi pembelajaran, maka dilakukan evaluasi. Alat yang dipergunakan dalam pengumpulan data aktivitas belajar adalah lembar observasi aktivitas belajar lompat jauh gaya jongkok. Dalam lembar observasi tersebut terdapat 6 kriteria penilaian aktivitas belajar peserta didik yaitu: kegiatan visual, lisan, audio, metrik, mental dan emosional. Pengamatan lembar format observasi aktivitas belajar diamati secara langsung oleh 1 orang evaluator (guru PJOK SMK Negeri 2 Singaraja) pada saat proses pembelajaran berlangsung.

Observasi hasil belajar teknik Lompat jauh gaya jongkok

1) Aspek Pengetahuan

Observasi atau evaluasi pengamatan hasil belajar aspek Pengetahuan dilakukan pada pertemuan II pada fase evaluasi proses pembelajaran, penilaian ini dilakukan oleh peneliti, evaluasi dilaksanakan dengan memberikan soal esay yang terkait dengan materi pembelajaran lompat jauh gaya jongkok

2) Aspek Sikap

Observasi atau evaluasi pengamatan hasil belajar aspek sikap dilakukan pada pertemuan II pada proses pembelajaran berlangsung, penilaian ini dilakukan oleh peneliti, evaluasi dilaksanakan dengan menggunakan lembar pengamatan lompat jauh gaya jongkok

\section{3) Aspek psikomotor}

Observasi atau evaluasi pengamatan hasil belajar aspek kterampilan dilakukan pada pertemuan II pada akhir pembelajaran, penilaian ini dilakukan oleh 1 orang evaluator yang terdiri dari 1 evaluator dari guru PJOK SMK Negeri 2 Singaraja.

\section{Refleksi Siklus I}

Setelah observasi dilakukan, peneliti mengkaji pelaksanaan tindakan dan mendiskusikan kekurangan-kekurangan pembelajaran pada siklus I. Berdasarkan hasil refleksi ini, peneliti dapat mengetahui kekurangan dan hambatan peserta didik. Apabila belum mencapai tujuan pembelajaran 
yang telah ditetapkan sesuai dengan kriteria ketentuan sekolah, maka akan direncanakan suatu alternatif pemecahan masalah pada siklus II, dimana permasalahan dan kekurangan yang terdapat pada siklus I dapat dipecahkan.

\section{Siklus II}

Seperti halnya siklus pertama, siklus kedua pun terdiri dari perencanaan, pelaksanaan, pengamatan/observasi dan refleksi.

Penelitian akan dilakukan pada peserta didik kelas XI Boga 2 SMK Negeri 2 Singaraja Tahun Pelajaran 2017/2018 Rencana penelitian ini akan dilaksanakan di lapangan Bhuana Patra dalam pembelajaran lompat jauh gaya jongkok pada jam ke 0 sampai jam ke 1, yaitu pukul 05.30 - 07.30 wita, dan penelitian ini akan dilaksanakan pada semester genap. Subyek yang akan digunakan dalam penelitian ini adalah peserta didik kelas XI Boga 2 SMK Negeri 2 Singaraja Tahun Pelajaran 2017/2018 yang berjumlah 39 orang peserta didik yang terdiri dari 18 orang peserta didik putri dan 21 orang peserta didik putra.

Dalam memperoleh data yang sesuai dengan tujuan peneliti, instrumen yang digunakan adalah lembar observasi aktivitas belajar peserta didik dan tes unjuk kerja lompat jauh gaya jongkok. Lembar observasi aktivitas belajar digunakan untuk mengukur tingkat aktivitas peserta didik selama proses pembelajaran. Sedangkan tes unjuk kerja digunakan untuk mengukur penguasaan halhal yang berkaitan dengan keterampilan gerak teknik lompat jauh gaya jongkok. Data tentang hasil belajar peserta didik dilakukan dengan menggunakan instrumen berupa assesemen. Analisis yang digunakan dalam penelitian ini adalah analisis aktivitas dan hasil belajar lompat jauh gaya jongkok yaitu menggunakan analisis Statistik Deskriptif.

\section{HASIL DAN PEMBAHASAN Hasil Penelitian}

Pada siklus I peserta didik yang berada pada kategori sangat aktif 5 orang $(12,8 \%)$, kategori aktif 14 orang $(35,9 \%)$, kategori cukup aktif 20 orang $(51,3 \%)$, dalam kategori kurang aktif $0(0 \%)$, dan tidak ada peserta didik yang berada sangat kurang aktif. Dari hasil analisis data diatas maka dapat dikatakan bahwa implementasi model pembelajaran NHT cukup efektif untuk meningkatkan aktivitas belajar lompat jauh gaya jongkok, hal ini dapat dilihat dari persentase ketuntasan belajar yang mencapai 48,7\% (19 orang).

Hasil belajar siklus I pada aspek pengetahuan, diketahui ketuntasan hasil belajar kompetensi pengetahuan lompat jauh gaya jongkok peserta didik secara klasikal yaitu sebesar 74,3\%. Hasil belajar siklus I pada aspek sikap, diketahui ketuntasan hasil belajar kompetensi pengetahuan lompat jauh gaya jongkok peserta didik secara klasikal yaitu sebesar 51,3\%. Hasil belajar siklus I pada aspek keterampilan, diketahui ketuntasan hasil belajar kompetensi pengetahuan lompat jauh gaya jongkok peserta didik secara klasikal yaitu sebesar $61,5 \%$. Hasil belajar kompetensi pengetahuan, sikap, dan keterampilan dikatakan berhasil atau tuntas secara klasikal apabila telah memenuhi standar kriteria ketuntasan minimal (KKM) sekolah untuk mata pelajaran PJOK sebesar 78 .

Berdasarkan hasil analisis data dari implementasi model pembelajaran kooperatif tipe NHT yang bertujuan untuk meningkatkan aktivitas dan hasil belajar lompat jauh gaya jongkok, hasil penelitian aktivitas belajar peserta didik pada siklus I terhadap pembelajaran pendidikan jasmani olahraga dan kesehatan khususnya pada materi lompat jauh gaya jongkok secara klasikal berada pada kategori cukup aktif. Dengan memperhatikan aktivitas dan hasil belajar lompat jauh gaya jongkok siklus I, peneliti melanjutkan ke siklus II dengan melihat permasalahanpermasalahan pada siklus I. Hal ini terbukti dari refleksi dari siklus I yang masih terdapat permasalahan-permasalahan dalam pelaksanaan tindakan.

Adapun permasalahan-permasalahan yang dihadapi dalam pembelajaran pada siklus I yaitu: (1) peserta didik kurang mendengarkan penjelasan dari peneliti tentang lompat jauh gaya jongkok (2) peserta didik 
kurang memperhatikan demonstrasi yang diperagakan oleh peneliti tentang lompat jauh gaya jongkok, (3) peserta didik kurang menaruh minat dan bersemangat dalam melakukan gerakan lompat jauh gaya jongkok, (4) peserta didik belum berani mengajukan pertanyaan dan mengemukakan pendapat karena takut dan malu ditertawakan temannya jika salah terkait lompat jauh gaya jongkok, (5) kurangnya pemahaman peserta didik terhadap model pembelajaran kooperatif tipe NHT, (6) peserta didik kurang bersemangat dan bersungguh-sungguh dalam melakukan lompat jauh gaya jongkok, (7) kurangnya kesempatan peserta didik dalam melakukan gerakan lompat jauh gaya jongkok sehingga hasilnya kurang maksimal.

\section{Berdasarkan}

permasalahanpermasalahan yang dihadapi pada siklus I tersebut maka adapun solusinya yaitu: (1) bagi peserta didik yang kurang mendengarkan saat pemberian materi, peserta didik tersebut akan dipanggil kedepan untuk menjelaskan materi yang sudah diberikan, (2) memberikan penghargaan berupa nilai plus bagi peserta didik yang bersungguh-sungguh pada saat melakukan gerakan lompat jauh gaya jongkok sehingga pandangan dapat mengarah ke depan, (3) memberikan pertanyaan mengenai materi yang sudah disampaikan agar peserta didik tidak ragu-ragu dalam menjawab pertanyaan yang di berikan, (4) mengimplementasi model pembelajaran kooperatif tipe NHT pada peserta didik secara lebih jelas dengan memberikan lembaran tahapan-tahapan pembelajaran kooperatif tipe NHT, (5) memberikan motivasi agar peserta didik menjadi lebih bersemangat dan bersungguh-sungguh dalam mengikuti pembelajaran pada siklus II tentang lompat jauh gaya jongkok, (6) membariskan peserta didik 2 bersaf agar peserta didik yang berada di belakang dapat memperhatikan lebih jelas mengenai materi yang disampaikan, (7) membagi peserta didik menjadi jumlah kelompok yang lebih banyak sehingga jumlah peserta didik dalam satu kelompok lebih sedikit sehingga kesempatan dalam melakukan gerakan di setiap peserta didik menjadi lebih banyak.
Pada pelaksanaan siklus II aktivitas belajar lompat jauh gaya jongkok peserta didik kelas XI Boga 2 SMK Negeri 2 Singaraja secara klasikal pada siklus II sebesar 7,1. Jika dilihat berdasarkan kriteria penggolongan aktivitas belajar berada pada rentang $7 \leq \bar{X}<9$ atau berada dalam kategori aktif. Hasil belajar pada aspek pengetahuan memiliki ketuntasan klasikal sebesar 92,3\%. Pada aspek sikap memiliki ketuntasan klasikal sebesar 89\% dan aspek keterampilan 81,7\%

Pembelajaran pada siklus II berlangsung sangat kondusif, peserta didik sudah mengetahui dan mampu beradaptasi dengan model pembelajaran kooperatif tipe NHT. Hal ini terlihat dari aspek aktivitas belajar peserta didik, saat peneliti memperagakan gerakan tidak lagi hanya menonton tetapi aktif bertanya terhadap penjelasan peneliti di setiap tahap gerakan yang diperagakan oleh peneliti. Rata-rata aktivitas belajar lompat jauh gaya jongkok secara klasikal tergolong aktif. Sedangakan untuk penguasaan materi lompat jauh gaya jongkok berada dalam kategori baik. Peningkatan ini tidak terlepas dari implementasi model pembelajaran kooperatif tipe NHT secara optimal dengan perbaikanperbaikan pembelajaran sesuai dengan kekurangan-kekurangan yang terjadi pada siklus sebelumnya.

\section{Pembahasan Hasil Penelitian}

Berdasarkan uraian diatas, ini berarti tingkat ketuntasan hasil belajar lompat jauh gaya jongkok pada siklus II sudah memenuhi standar ketuntasan secara klasikal yaitu sebesar 78 sesuai dengan KKM di SMK Negeri 2 Singaraja. Peningkatan aktivitas dan hasil belajar pada siklus II tersebut dikarenakan: 1) penggunaan model pembelajaran kooperatif tipe NHT dengan pembelajaran berkelompok sudah dipahami oleh peserta didik dan 2) peneliti melakukan perbaikan berdasarkan kendala-kendala yang dialami pada siklus I.

Meskipun pelaksanaan siklus II dinyatakan berhasil, tetapi masih terdapat kendala-kendala yang dihadapi saat penerapan model pembelajaran kooperatif tipe NHT, yaitu: terbatasnya waktu pelaksanaan penelitian sehingga peserta didik kekurangan waktu untuk lebih memahami tahapan- 
tahapan model pembelajaran yang peneliti terapkan. Dengan adanya kendala tersebut solusi yang peneliti sarankan kepada guru yaitu untuk selanjutnya agar lebih sering menerapkan model pembelajaran kooperatif tipe NHT dalam pembelajaran PJOK, sehingga peserta didik akan semakin paham dengan struktur pembelajaran dalam model pembelajaran kooperatif tipe NHT.

Dari sekian banyak model pembelajaran kooperatif yang ada, salah satunya adalah model pembelajaran kooperatif tipe NHT. Dimana dengan melihat aktivitas dan hasil belajar lompat jauh gaya jongkok ditemukan hasil bahwa dengan mengimplementasikan model pembelajaran kooperatif tipe NHT aktivitas dan hasil belajar peserta didik meningkat dalam materi lompat jauh gaya jongkok. (Trianto, 2007:62).

Penelitian yang sudah dilaksanakan ini tidaklah selalu berjalan dengan lancar sesuai dengan yang diharapkan dan yang sudah direncanakan. Karena ada kendala-kendala yang dihadapi peneliti dalam menjalankan penelitian ini. Adapun kendala-kendala yang dihadapi adalah: (a) jumlah alat-alat pendukung yang kurang dari jumlah kelompok belajar yang sudah direncanakan, (b) respon peserta didik untuk memahami materi lambat sehingga harus dijelaskan berulang-ulang.

Dari kendala-kendala yang dihadapi tersebut adapun yang dilakukan peneliti untuk memecahkannya sehingga penelitian yang dilakukan dapat berjalan dengan lancar diantaranya adalah: (a) menggunakan lapangan Bhuana Patra yang sudah ada dan alat yang dimiliki oleh peserta didik, (b) menggunakan kerdus yang sudah ada dan untuk kekurangan Bak Lompat, dan (c) menjelaskan kembali secara berulang-ulang materi yang belum dimengerti.

\section{PENUTUP \\ Simpulan}

Berdasarkan hasil analisis data dan pembahasan di atas dapat ditarik simpulan sebagai berikut. (1) Aktivitas belajar lompat jauh gaya jongkok meningkat melalui implementasi model pembelajaran kooperatif tipe NHT pada siswa kelas XI Boga 2 SMK
Negeri Singaraja tahun pelajaran 2017/2018. (2) Hasil belajar lompat jauh gaya jongkok meningkat melalui implementasi model pembelajaran kooperatif tipe NHT pada siswa kelas XI Boga 2 SMK Negeri 2 Singaraja tahun pelajaran 2017/2018.

\section{Saran}

Berdasarkan simpulan di atas, dapat dikemukakan saran-saran sebagai berikut. (1) Guru PJOK hendaknya mengimplementasi model pembelajaran kooperatif tipe NHT sebagai salah satu alternatif pembelajaran karena terbukti dapat meningkatkan aktivitas dan hasil belajar lompat jauh gaya jongkok pada peserta didik. (2) Bagi sekolah dapat dijadikan sebagai pedoman dalam pembelajaran PJOK khususnya pada materi lompat jauh gaya jongkok guna meningkatkan aktivitas dan hasil belajar. (3) Diharapkan kepada peserta didik yang dijadikan subjek penelitian selanjutnya lebih memperhatikan dan memahami pembelajaran yang diberikan agar dapat menambah wawasan pengetahuan khususunya dalam pembelajaran materi lompat jauh gaya jongkok maupun pada pembelajaran yang lain.(4) Guru atau peneliti lain diharapkan melakukan penelitian tindakan lanjutan dengan mengimplementasikan pendekatan saintifik dan model pembelajaran kooperatif tipe NHT pada kompetensi dasar yang lain, untuk mengetahui bahwa model pembelajaran ini tidak hanya dapat diterapkan pada pembelajaran atletik, khususnya lompat jauh gaya jongkok.

\section{DAFTAR PUSTAKA}

Arikunto, S. 2002. Prosedur Penelitian. Jakarta: Rineka Cipta.

Astrawan, I Gede Budi.2012."Penerapan Model Kooperatif Tipe NHT Dalam Meningkatkan Hasil Belajar Siswa Pada Mata Pelajaran IPA Di Kelas V SD N 3 Tonggolobibi. Jurnal Kreatif Tadulako Online Vol. 3 No. 4ISSN 2354-614X

Bawa, I Made Lanang. 2012. Implementasi Model Pembelajaran Kooperatif Tipe 
NHT Untuk Meningkatkan Aktivitas Dan Hasil Belajar Teknik Dasar Passing Sepakbola Pada Siswa Kelas X1 Sma Negeri 1 Sukasada Tahun Pelajaran 2011/2012. Skripsi (tidak diterbitkan). Jurusan Penjaskesrek, Undiksha Singaraja.

Mutia Agisni Mulyana, Nurdinah Hanifah, Asep Kurnia Jayadinata. 2016. Penerapan Model Kooperatif Tipe Numbered Heads Together (NHT) Untuk Meningkatkan Hasil Belajar Siswa Pada Materi Kenampakan Alam Dan Sosial Budaya. Jurnal Pena Ilmiah UPI. Vol 1 No 1.

Nursyamsi SY, Aloysius Duran Corebima, Herawati Susilo. 2016. Pengaruh Strategi Pembelajaran Numbered Heads Together (NHT) terhadap Hasil Belajar Siswa SMA Negeri 1 Muara Badak. Jurnal Pendidikan: Teori, Penelitian, dan Pengembangan. Vol 1 No 10 Edisi Oktober.

Rasyid Dan Mansur. (2008). Penilaian Hasil Belajar.Bandung: CV Wacana Prima Jurnal Kreatif Tadulako Online Vol. 3 No. 4ISSN 2354-614X242

Rika Fima Yenni. 2016. Penggunaan Metode Numbered Head Together (NHT) Dalam Pembelajaran Matematika. Jurnal Penelitian dan Pembelajaran Matematika. Jurnal Penelitian dan Pembelajaran Matematika. Vol 9 No 2.

Siti Nuryanti. 2014. Penerapan Model Pembelajaran Kooperatif Tipe Numbered Head Together (Nht) Untuk Meningkatkan Hasil Belajar Siswa Pada Mata Pelajaran Ipa Kelas IV Sd Negeri 3 Tondo. Jurnal Diknas. Volume 2 No 2.
Sanjaya, I Putu Eka. 2013 Penerapan Model Pembelajaran Kooperatif Tipe NHT Untuk Meningkatkan Motivasi Dan Hasil Belajar Teknik Dasar Passing Bola Basket Pada Siswa Kelas X5 SMA Negeri 1 Negara Tahun Pelajaran 2012/2013. Skripsi (tidak diterbitkan). Jurusan Penjaskesrek, Undiksha Singaraja.

Slameto. (2003). Belajar Dan Faktor-Faktor Yang Mempengaruhinya. Jakarta: Rineka Cipta.

Suryanto. (2009). Evaluasi Pembelajaran Di SD. Jakarta: Universitas Terbuka.

Syuaib, Dahlia. (2012). Penelitian Tindakan Kelas. Palu: Edukasi Mitra Grafika

Trianto. 2007. Model-Model Pembelajaran Inovatif Berorientasi Konstruktivistik. Jakarta: Prestasi Pustaka.

Widodo, Lusi Widayanti. 2013. Peningkatan Aktivitas Belajar Dan Hasil Belajar Siswa Dengan Metode Problem Based Learning Pada Siswa Kelas Viia Mts Negeri Donomulyo Kulon Progo. Jurnal Fisika Indonesia No: 49, Vol XVII, Edisi April. 